\title{
3D lithostratigraphic model of the Paleogene of the onshore part of the Moesian Platform (Northeast Bulgaria)
}

\author{
Boris Valchev ${ }^{1}$, Dimitar Sachkov¹, Sava Juranov² \\ ${ }^{1}$ University of Mining and Geology "St Ivan Rilski”, Department of Geology and Geoinformatics, 1 Prof. Boyan Kamenov Str., \\ Studentski Grad,1700 Sofia,Bulgaria; e-mail:b_valchev@mgu.bg; dimitarsachkov@gmail.com \\ ${ }^{2}$ Sofia University "St Kliment Ohridski”, Department of Geology, Palaeontology and Fossil Fuels, 15 Tsar Osvoboditel Blvd, \\ 1504 Sofia, Bulgaria, e-mail: juranov@gea.uni-sofia.bg
}

(Accepted in revised form: March 2018)

\begin{abstract}
The Paleogene sedimentary rocks in the north-easternmost part of the territory of Bulgaria have been penetrated by numerous boreholes. In terms of regional tectonic zonation, the study area is a part of the onshore sector of the Moesian Platform, which partly includes the South Dobrogea Unit and the easternmost part of the North Bulgarian Dome with its eastern slope. The lithostratigraphy of the Paleogene successions consists of six formal units (the Komarevo, Beloslav, Dikilitash, Aladan, Avren, and Ruslar formations) and one informal unit (glauconitic marker). For compiling an overall conception of the regional aspects (lithology, thickness, spatial distribution, and relationships) of the individual lithostratigraphic units and for illustration of their spatial distribution, a 3D lithostratigraphic model based on reinterpretation of individual borehole sections has been created. The model database was compiled by integration of the original lithological data from 338 borehole sections.
\end{abstract}

Valchev, B., Sachkov, D., Juranov, S. 2018. 3D lithostratigraphic model of the Paleogene of the onshore part of the Moesian Platform (Northeast Bulgaria). Geologica Balcanica, 47 (1), 23-36.

Keywords: 3D model, lithostratigraphy, Paleogene, Moesian Platform, north-eastern Bulgaria.

\section{INTRODUCTION AND GEOLOGICAL SETTING}

The Paleogene sedimentary rocks are largely distributed in the north-easternmost part of the territory of Bulgaria, as they have been established by means of numerous boreholes. These rocks were referred to different formal and informal lithostratigraphic units during the geological investigations in the second half of the $20^{\text {th }}$ century (see Cheshitev et al., 1995; Filipov, 1995). The aims of this work are: (i) to elucidate the exact lithostratigraphic succession; (ii) to refine the lithostratigraphic scheme, (iii) to illustrate the spatial distribution and relationships of the individual Paleogene lithostratigraphic units by using 3D modelling, based on reinterpretation of borehole sections, and thus (iv) to clarify the Paleogene part of the deep geologic structure of this sector of the territory of northeastern Bulgaria.

In terms of the regional tectonics, the studied area comprises a part of the onshore sector of the Moesian Platform (Fig. 1a), including partly the South Dobro- gea Unit (Georgiev, 2012), which is also known as the Dobrogea Massive (Bokov et al., 1987; Dabovski and Zagorchev, 2009), as well as the easternmost part of the North Bulgarian Dome with its eastern slope (Dabovski and Zagorchev, 2009). As a whole, this region represents a mosaic of relatively small, vertically displaced blocks (Georgiev, 2012). It is generally composed of Paleozoic basement and Mesozoic-Neozoic sedimentary cover (Bokov et al., 1987; Cheshitev et al., 1995; Filipov, 1995; Dabovski and Zagorchev, 2009). The latter consists of Triassic, Jurassic-Lower Cretaceous carbonate platform sequences and Upper Cretaceous to Miocene shallow-marine carbonate and siliciclastic deposits. The eastern slope of the North Bulgarian Dome (also known as Varna Monocline - Bokov et al., 1987), comprising almost the entire study area (Fig. 1b), is formed on the southwards to south-eastwards dipping Upper Jurassic-Lower Cretaceous carbonate complex, which is covered by a thick succession of Upper Cretaceous, Paleogene and Neogene deposits (Dabovski and Zagorchev, 2009). 

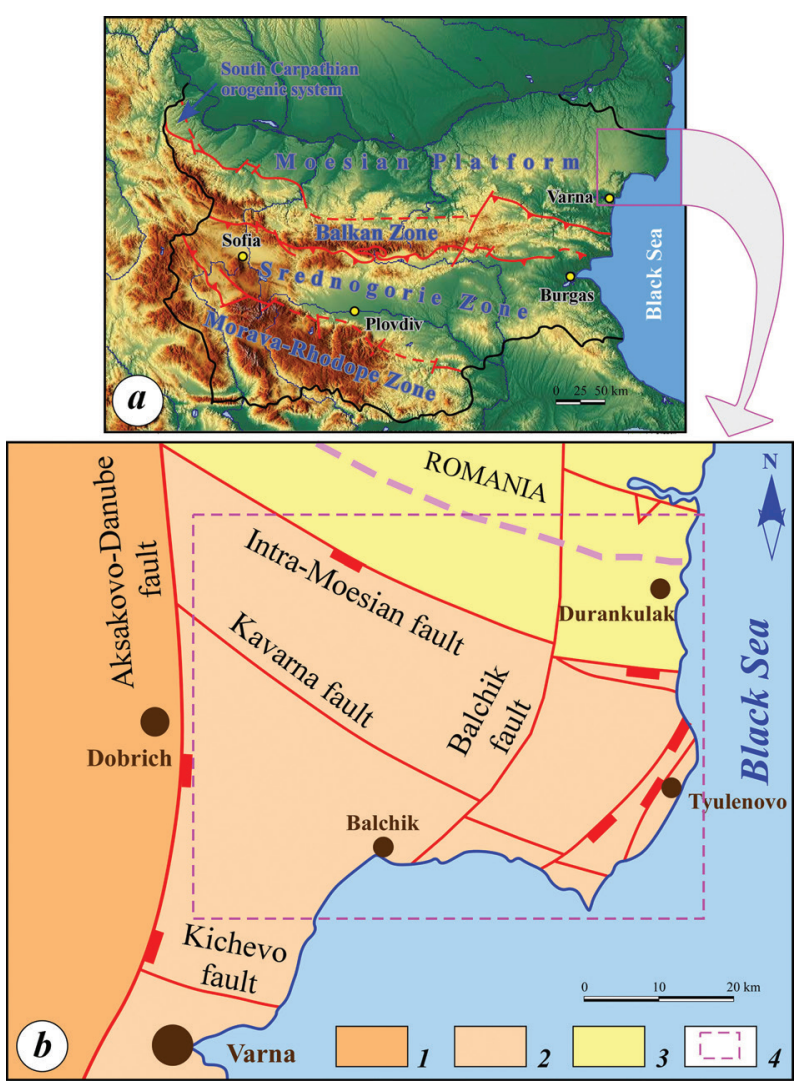

Fig. 1. a) Tectonic subdivision of the territory of Bulgaria (after Dabovski and Zagorchev, 2009) with location of the studied area; $b$ ) Tectonic subdivision of the onshore part of the Moesian Platform in Northeast Bulgaria (after Georgiev, 2012): 1 - North Bulgarian Dome; 2 - eastern slope of North Bulgarian Dome; 3 - South Dobrogea Unit; 4 - area of 3D modelling.

\section{MATERIAL AND METHODS}

The present investigation is based on integration of the primary lithological data from over 640 onshore borehole sections (the geological reports are kept at the National Geological Fund, Ministry of Energy of the Republic of Bulgaria), which are unevenly distributed across the studied area. The boreholes were drilled and studied from the early 1950s to the late 1980s, for oil and gas prospecting, and concern the following areas: Tyulenovo (Petuhov et al., 1952, 1954; Miteva, 1964; Chervenakov and Troshanov, 1965; Tochkov, 1967, 1968; Nikolova, 1974), Spasovo (Darakchiev and Veneva, 1958; Bogdanova and Dencheva, 1964); Balchik (Darakchiev and Veneva, 1958; Nedev, 1961); Krapets-Durankulak (Monahov and Veneva, 1960; Nikolova, 1965); Dobrich (Nedev, 1965; Nikolova, 1980); Kardam (Nikolova, 1967; Vavilova, 1974); south-eastern Dobrogea (Petuhov et al., 1952; Nikolova, 1971, 1973); Balgarevo (Petuhov et al., 1952; Tochkov, 1972; Nikolova, 1974); Gorun (Nikolova, 1974, 1975); Shabla (Nikolova, 1979); and Tvarditsa
(Panayotov, 1960), as well as the prospecting of the Dobrogea coal basin (Petuhov et al., 1952; Monzelevski et al., 1970; Stoyanov et al., 1979, 1982, 1998) and the Obrochishte manganese deposit (Petuhov et al., 1952; Bogdanova, 1965, 1976; Vasilev et al., 1967; Nedev et al., 1970; Aneva et al., 1979). For collection of the model database, a lithostratigraphic interpretation and reinterpretation of 338 individual borehole sections was made (see Fig. 2). As a result, an overall conception of the regional aspects (lithology, thickness, spatial distribution, and relationships) of the individual lithostratigraphic units was compiled. A 3D model for the whole area, as well as two additional models, was created. The generating of the two additional models is due to the uneven distribution of the borehole sections, as the additional models concern the areas with dense (clustered) borehole network (between the village of Vranino and the town of Kavarna, as well as between the town of Shabla and the village of St Nikola; Fig. 2, areas 1, 2).

The 3D modelling followed two steps of software processing: initial creation of the bodies, using RockWorks Geological modelling software, and final visualization by means of ArcScene. The creation of the lithostratigraphic bodies is based on: (i) software dividing into individual voxels with size $200 \times 200 \times 1 \mathrm{~m}$ for the full model, and $100 \times 100 \times 1 \mathrm{~m}$ for the additional ones; (ii) statistical processing by Kriging method, with a maximum radius of $5 \mathrm{~km}$ search to avoid errors caused by incorrectly reported elevations for the individual boreholes; (iii) excluding bodies thinner than $1 \mathrm{~m}$, as they were considered a result of statistical data processing; (iv) using the onlap function, which allows a more realistic representation of the bedding of each unit.

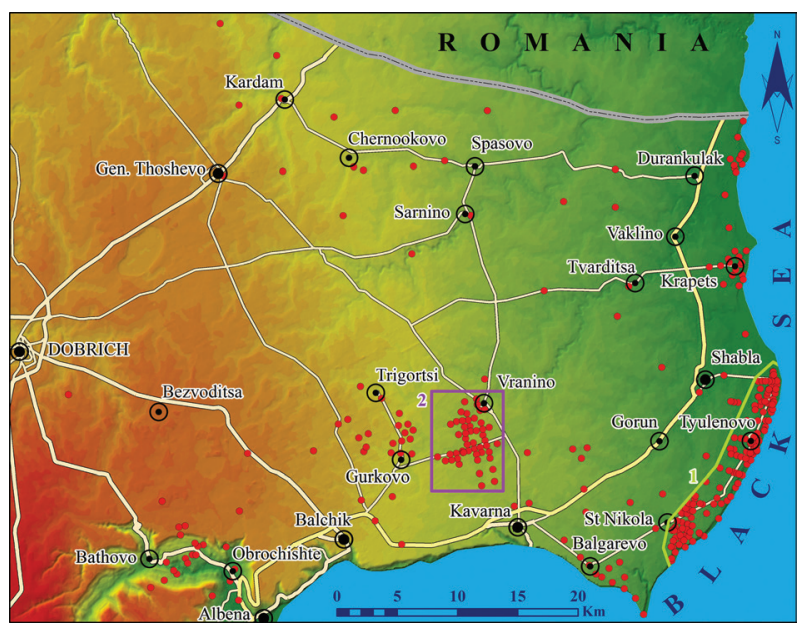

Fig. 2. Distribution of the borehole sections used in the 3D modelling: 1 (green polygon) and 2 (violet polygon) are areas with larger scale modelling (shown in Figs 6, 7) due to the dense (clustered) distribution of the boreholes. 
The created bodies were imported in ArcScene for final visualization. For a realistic view of the model, concerning the thickness of the lithostratigraphic units, tenfold vertical stretching of the bodies was made and, in order to view their spatial distributions, the gaps between the individual units or their parts were set.

\section{LITHOSTRATIGRAPHIC UNITS AND REGIONAL LITHOSTRATIGRAPHIC ASPECTS}

On the base of the primary lithological data from the geological reports, we identified seven lithostratigraphic units (six formal and one informal) in the Paleogene succession of the studied region, which are as follows (Fig. 3): the Komarevo Formation; glauconitic marker; the Beloslav Formation; the Dikilitash Formation; the Aladan Formation; the Avren Formation, and the Ruslar Formation. The Paleogene lithostratigraphic units demonstrate varieties in their spatial distributions and relationships throughout the studied area. A brief description for each unit is given bellow.

\section{The Komarevo Formation}

It was first described as the informal "Kaylaka formation” by Datchev (1967) in Pleven District (central North Bulgaria) and later formalized as the Komarevo Formation (Datchev, 1975). In northeastern Bulgaria, it was known as "lower calcareous horizon of the Thanetian” (Belmoustakov, 1962), "limestone formation” (Aladjova-Khrischeva, 1984), and in Varna region the rocks were referred to the Komarevo Formation by Aladžova-Hrisčeva (1990). The unit was also described as "Yunak Formation" (Juranov, 1990), which is nomen nudum. The Komarevo Formation comprises an alternation of sandy limestones and organogenic limestones with numerous gradual vertical and lateral transitions between them. The sandy limestones are grey to greenish, thin- to medium-bedded, micritic, containing glauconite grains at the base of the unit. Chert nodules are locally common. The organogenic limestones are white to grey, mainly detritic (remains of lithothamnium algae and nummulitids), thin-bedded. The chronostratigraphical range of the Komarevo Formation in the studied area has been determined as upper Paleocene (Thanetian) based on planktonic foraminifera (Juranov, unpublished data).

The lithobody tentatively referred herein to the Komarevo Formation shows consistent lithological characteristics throughout the whole area of its distribution, although they differ considerably from these in the type area in central North Bulgaria (Datchev, 1975). The thickness of the unit is 10-15 m, rarely up to $26 \mathrm{~m}$ (in the area of Tyulenovo), and it increases gradually from the west to the east and southeast. The unit covers different levels of the Upper Cretaceous (usually the Mezdra Formation introduced by Yolkichev, 1986), as the boundary is an unconform- ity. The upper boundary is a sharp lithological contact or unconformity with different units of the Paleogene section (glauconitic marker, Beloslav or Dikilitash Formation, Aladan Formation).

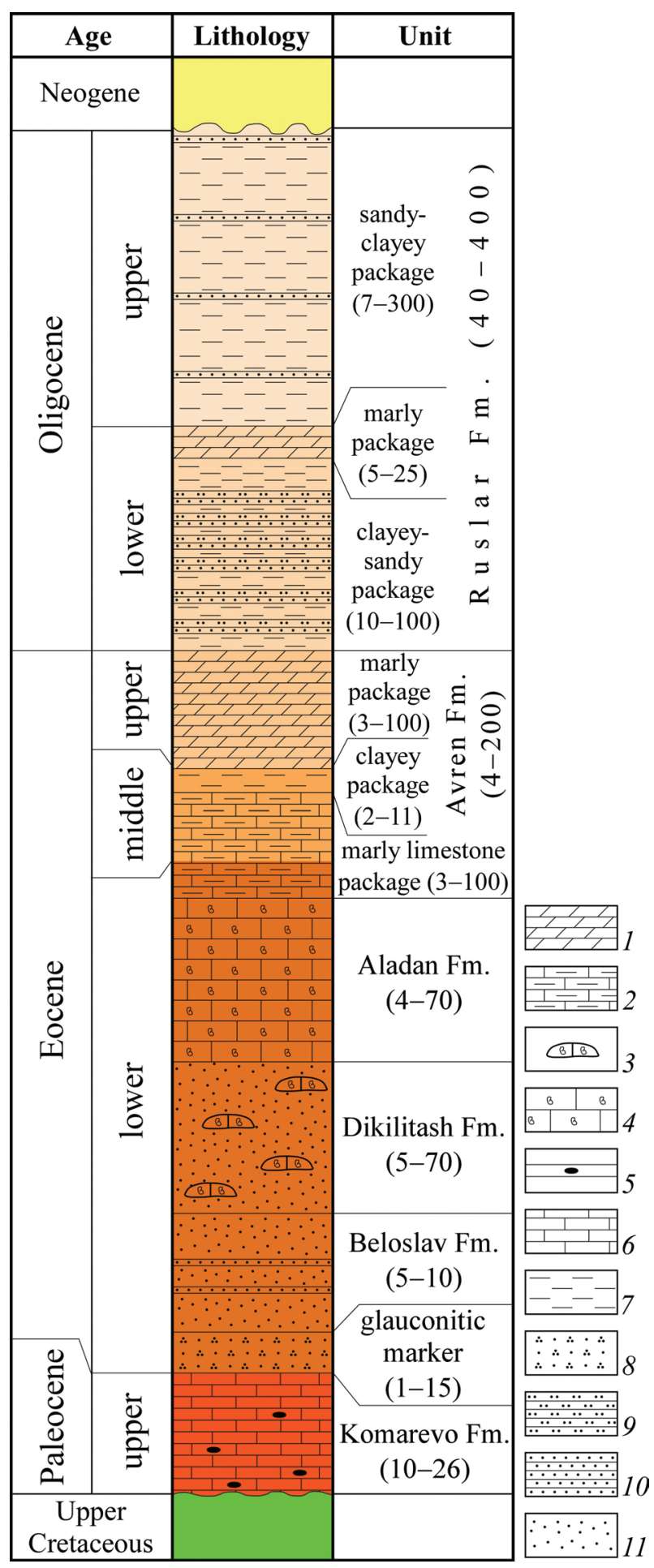

Fig. 3. General scheme of the Paleogene lithostratigraphic units: 1 - marls; 2 - marly limestones; 3 - bioherms; 4 - organogenic limestones; 5 - chert nodules; 6 - limestones; 7 - clays; 8 - glauconitic sandstones and glauconites; 9 - siltstones; 10 sandstones; 11 - sands. 


\section{Glauconitic marker}

It was described as "Gorun Formation" (Juranov, 1990), which is nomen nudum. The glauconitic marker is composed of green to dark grey thick-bedded clayey-glauconitic siltstones passing into glauconitites. Quartz, muscovite and pyrite grains represent the silt component. No fossil data were recorded from the onshore sections. Thus, the chronostratigraphical range (lowermost lower Eocene) of the glauconitic marker has been determined based on its stratigraphic position. In a single offshore section (Yuri Shimanov borehole), a nannofossil assemblage, characteristic for zones NP9-NP10 (uppermost part of the Thanetianlowermost part of the Ypresian) was found in glauconitic sandstones referred to the Beloslav Formation (Stoykova, 2008).

The glauconitic marker shows strong unchangeable lithological characteristics throughout the whole area of its distribution. Its thickness varies; generally, it is $1-2 \mathrm{~m}$ in the majority of the sections (for example, in the areas of Tyulenovo and Balgarevo), but there are some exceptions (6-7 $\mathrm{m}$ in Makedonka area of the Dobrogea coal basin to $10-15 \mathrm{~m}$ in the areas of Vranino and Krapets-Durankulak). The lower boundary is a sharp contact (hiatus) with the Komarevo Formation or different units of the Upper Cretaceous (usually the Mezdra Formation). The upper boundary represents a sharp lithological contact with the Beloslav or Dikilitash formations (in the western part of the studied area), or a gradual transition to the Aladan Formation.

\section{The Beloslav Formation}

It was first described as "horizon of yellow beds" by Gočev (1933), and Aladjova-Khrischeva (1984) formalized the unit (see also Juranov, 1993c). It comprises yellowish clayey fine- to medium-grained loose sandstones and sands interbedded with white carbonate thin-bedded $(10-15 \mathrm{~cm})$ sandstones. In the upper levels, white medium-grained quartz sands without bed surfaces occur. The transition between these lithological types is gradual. The chronostratigraphical range of the Beloslav Formation is lower Eocene (lower part of the Ypresian), which has been determined based on nummulitic assemblages (AladjovaKhrischeva, 1984).

The Beloslav Formation is usually 5-10 m thick. The lower boundary is an unconformity with different levels of the Upper Cretaceous, the Komarevo Formation, or it is a sharp lithological contact with the glauconitic marker. The upper boundary is a gradual transition to the Dikilitash Formation.

\section{The Dikilitash Formation}

This unit was introduced as "Dikili Tash horizon" by Gočev (1933). Subsequently, Aladjova-Khrischeva (1984) described it as a formal unit (see also Juranov, 1993d). It is composed of white thick-bedded loose, indistinctly bedded quartz sands, calcareous sandstones and thin interbeds of light-beige biomorphic (nummulitic and algal) limestones representing bioherms. In the area of Lake Beloslav, west of the town of Varna, these bioherms form stone columns, which are unique and world-famous geological phenomenon (Nachev and Sinnyovsky, 2014). The chronostratigraphical range of the Dikilitash Formation has been determined as lower Eocene (Ypresian) based on nummulitic assemblages (Aladjova-Khrischeva, 1984).

The Dikilitash Formation shows variations in its thickness from 5-6 m (Kardam area) to $70 \mathrm{~m}$ (Spasovo area). Its lower boundary is indistinct (broad gradual transition) with the Beloslav Formation, and the upper boundary is a sharp lithological contact with the Aladan Formation. There is a single case near the village of Balgarevo, where the unit is covered by the Avren Formation.

Based on the available lithological data in the majority of the sections, it is difficult or impossible to separate the Beloslav and Dikilitash Formations, and therefore they were examined together. The lithology of this body is constant throughout the whole area of its distribution, while the thickness varies in broad limits: from 5-6 $\mathrm{m}$ in Kardam area to 60-70 $\mathrm{m}$ in Spasovo area to the north; and from $72 \mathrm{~m}$ in the north-western part of Balchik area to $4 \mathrm{~m}$ in the area of Vranino to the south.

\section{The Aladan Formation}

It was introduced as "Aladan limestone" by Gočev (1933) and also described as "Strashimirovo limestones” by Bonchev (1960). It was formalized by Aladjova-Khrischeva (1984; see also Juranov, 1993b). It consists of sandy or biomorphic limestones. The skeletal materials include mainly nummulitic shells, as well as bryozoans, echinoids, brachiopods. The limestones are strongly fractured, as the organogenic ones are cavernous. The chronostratigraphical range of the Aladan Formation has been determined as lower Eocene (upper part of the Ypresian) on the base of nummulitic (Aladjova-Khrischeva in: AladjovaKhrischeva et al., 1983; Aladjova-Khrischeva, 1984), nannofossil (Muzilev in: Aladjova-Khrischeva et al., 1983) and planktonic foraminiferal data (Dzuranov and Darakchieva, 1986).

The Aladan Formation demonstrates different thicknesses compared to its type area near the town of Beloslav (5-10 m). Here, it is $30 \mathrm{~m}$ on average and varies broadly from 3-4 $\mathrm{m}$ in the areas of Kardam and Tyulenovo to over $50 \mathrm{~m}$ in the area of Krapets-Durankulak, where it forms a typical reef platform. The colour of the rocks also changes from the west (grey) to the east (greenish) due to the presence of glauconite grains. The lower boundary is an unconformity with the Upper Cretaceous levels, the Komarevo Formation, or the glauconitic marker, and a sharp contact with the Dikilitash Formation. The unit is usually 
covered by the Avren Formation, but in some sections the boundary represents unconformity with the Ruslar Formation (between the villages of Tvarditsa and Krapets) or with the Neogene successions (in the northwesternmost part of the studied area).

\section{The Avren Formation}

This unit was introduced as "Avren marls" (Gočev, 1933). Synonyms: "Arnautlar marls” (Bontchev, 1926), "Ruslar horizon” (pars; Gočev, 1933) and “Momino marls” (Belmoustakov in: Bončev et al., 1957). Additional lithological data were given by Mandev (1955) and Belmoustakov (1962). The rank of formation was determined by Dzuranov and Darakchieva (1986; see also Juranov, 1993a). Generally, the Avren Formation consists of pale-grey to grey-greenish or brownish thin-bedded, pure, sandy or limy marls interbedded with clayey limestones, sandstones and siltstones, marls being the main lithological type. The chronostratigraphical range of the unit has been determined based on planktonic foraminifera (Dzuranov and Darakchieva, 1986) and nannofossils (Muzilev in: Aladjova-Khrischeva et al., 1983) as uppermost lower Eocene (uppermost part of the Ypresian)-upper Eocene (Priabonian).

The Avren Formation is characterized by variability in its lithological features. In the studied area, the lower levels of the unit comprise a distinct package of thin-bedded clayey to marly limestones, $6 \mathrm{~m}$ to over $100 \mathrm{~m}$ thick (in the areas of Tyulenovo, Kavarna, Balgarevo). In our 3D model, this level is named as marly limestone package. In the central, south-western, and south-easternmost part of the area, a thin (2.5 $\mathrm{m}$ to 11 $\mathrm{m})$ body of non-carbonate dark-grey to brown thinbedded clays is clearly distinguished (clayey package in the model), covering the marly limestones. They contain numerous remains of fishes (particles of squames and bones), foraminifera and plants. The upper levels of the Avren Formation are represented by a package of thin-bedded marls, $3 \mathrm{~m}$ to over $100 \mathrm{~m}$ thick, with numerous remains of small foraminifera (marly package in the model). Thus, the total thickness varies from 3-4 m to $200 \mathrm{~m}$. Generally, it increases from the northwest to southeast. All the three packages show stable lithological characteristics throughout the area of their distributions. The lower boundary is usually a fast gradual transition with the Aladan Formation. A single case of the Avren Formation covering the Upper Cretaceous rocks was recorded in Tyulenovo area. The upper boundary with the Ruslar Formation is a sharp lithological contact or an unconformity in the cases when there are no clayey or marly packages (in the areas of Trigortsi and Vranino).

\section{The Ruslar Formation}

It was introduced as "Ruslar sandstones” by Zlatarski (1927) and formalized by Aladjova-Chrisčeva (1991; see also Juranov, 1993e). It is composed of various lithologies including clays, siltstones, sandstones, diatomite, spongolites, tuffs and manganese ores, with numerous transitions between them. The main lithological type is clays. They are grey, grey-greenish, brownish, pure non-carbonate or unevenly calcareous. The siltstones are dark-grey to greenish, weakly cemented, thin-bedded, containing glauconite grains. The sandstones are grey, fine- to medium-grained, with muddy matrix. The marls are green, silty, and thin-bedded. The manganese ores occur at several levels throughout the section, representing single interbeds or compact ore zone, several tens of meters thick. The chronostratigraphical range has been determined as Oligocene based on rare finds of planktonic foraminifera (Juranov, unpublished data).

The Ruslar Formation is the most diverse lithostratigraphic unit in the studied area from lithological point of view. As a whole, its lower levels represent a package (10 m to over $100 \mathrm{~m}$ thick; usually $20 \mathrm{~m}$ to $70 \mathrm{~m}$ ), comprising predominantly sandstones, siltstones and clays. The ore deposits are also characteristic of this level. In the 3D model, it is named clayey-sandy package. At the middle levels of the formation, amongst the clays, a distinct, widespread marl package, containing abundant ostracod remains, was distinguished (marly package in the model). Its thickness is almost uniform (6-10 m), but there are single exceptions (less than $5 \mathrm{~m}$ and over $25 \mathrm{~m}$ ). The upper levels of the formation are dominated by clays, which form the next distinct package (7 $\mathrm{m}$ to $300 \mathrm{~m}$ thick sandy-clayey package in the model). Here, the sandstones, diatomites and siltstones are present as thin interbeds. The packages demonstrate constant lithological characteristics throughout the area of their distributions, but there are considerable variations in their thicknesses. Generally, they increase from the northwest to the southeast, but in Gurkovo-Vranino area the clayey-sandy and marly packages are thickest, while the thickest sandy-clayey one was recorded in Balgarevo-Kaliakra area. The total thickness of the Ruslar Formation varies from tens of meters to over 300 m (Balgarevo-Kaliakra area). Its lower boundary with the underlying Avren Formation is a sharp lithological contact or unconformity, and in the single cases, where it covers the Aladan Formation, the boundary represents an unconformity. The upper boundary with the Neogene succession is also an unconformity.

\section{Regional lithostratigraphic aspects}

Examples of the distinguished lithostratigraphic successions in different localities are shown in Fig. 4 by illustration of 21 representative borehole sections. It can be seen that the thinnest Paleogene succession was recorded in Kardam area (5-40 m), where only the loose terrigenous rocks of the Beloslav or Dikilitash formations, covered with the organogenic limestones of the Aladan Formation (Fig. $4 a, b$ ), are pre- 
C-3 Kardam
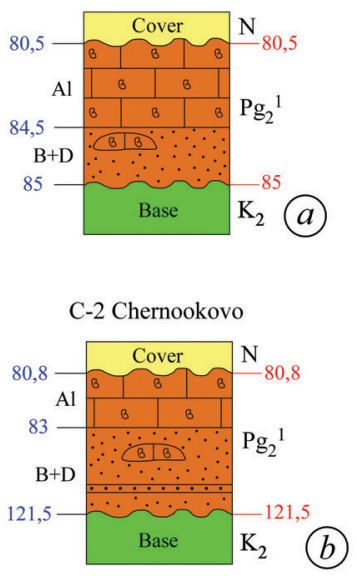

C-1 Tvarditsa
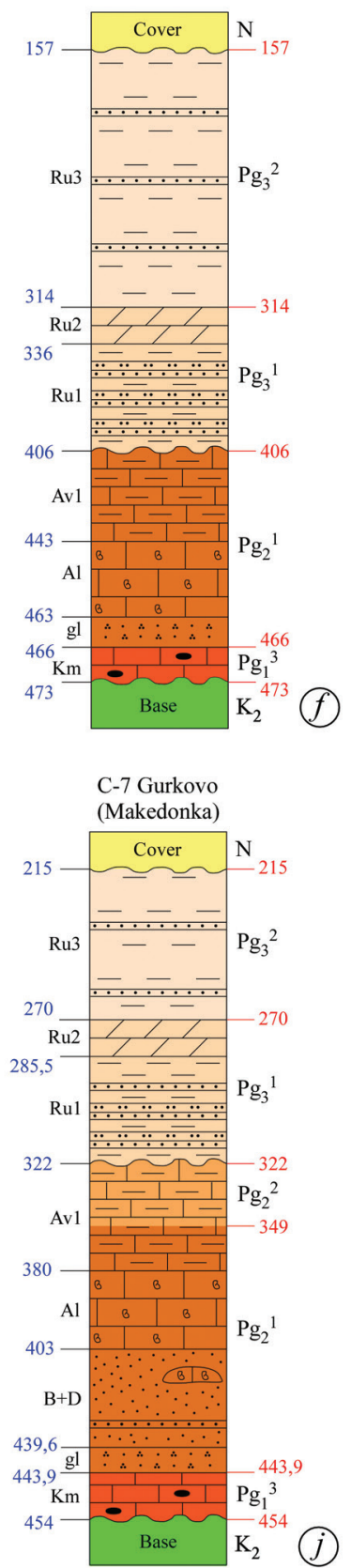

C-13 Spasovo

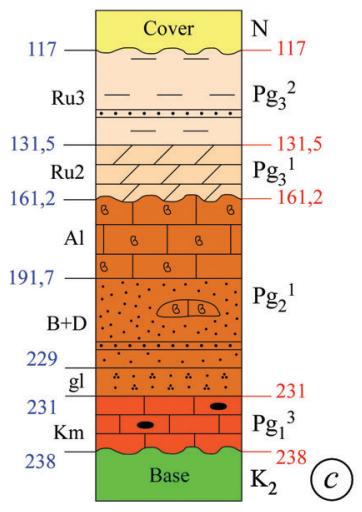

C-52 Tvarditsa

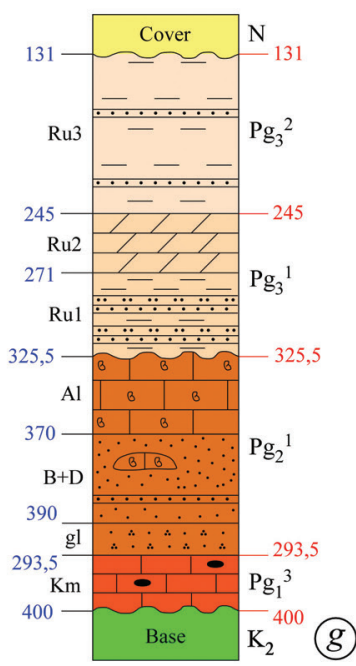

C-27 Balchik

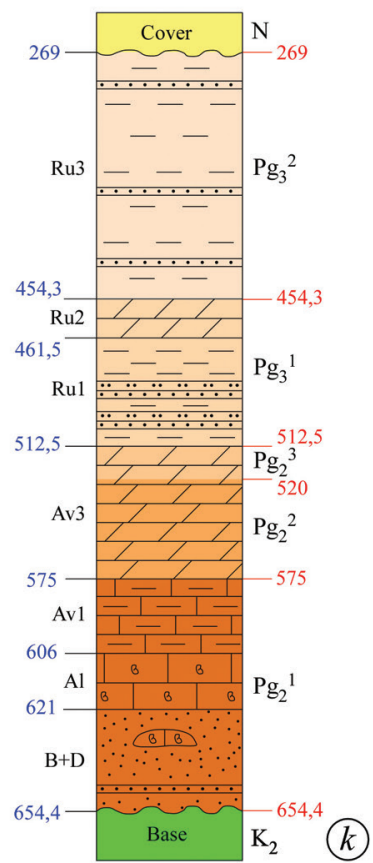

C-222 Durankulak

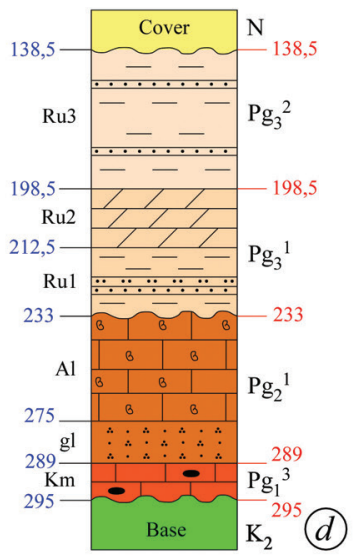

\section{C-215 Krapets}

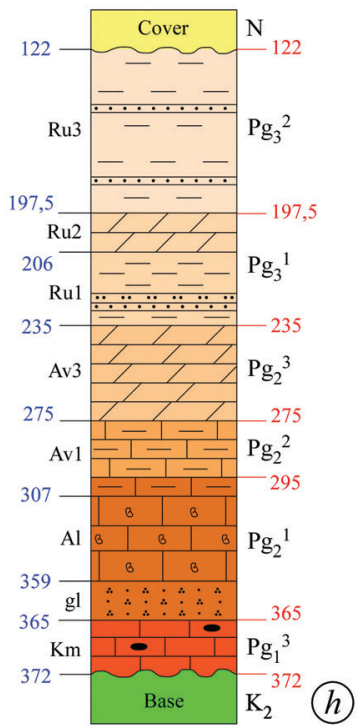

C-24 Balchik

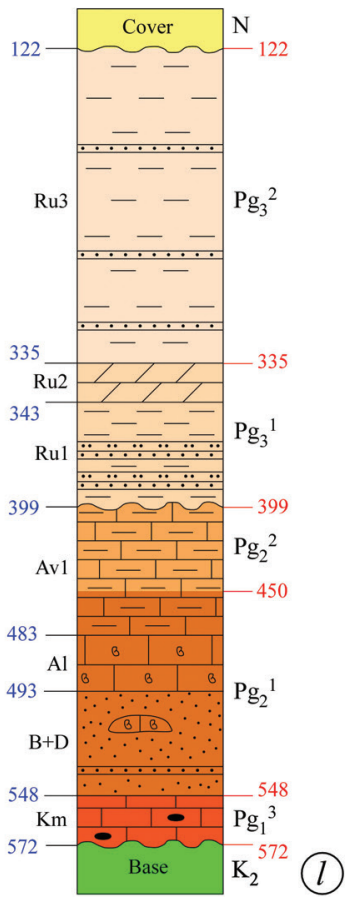

C-48 Shabla Lake
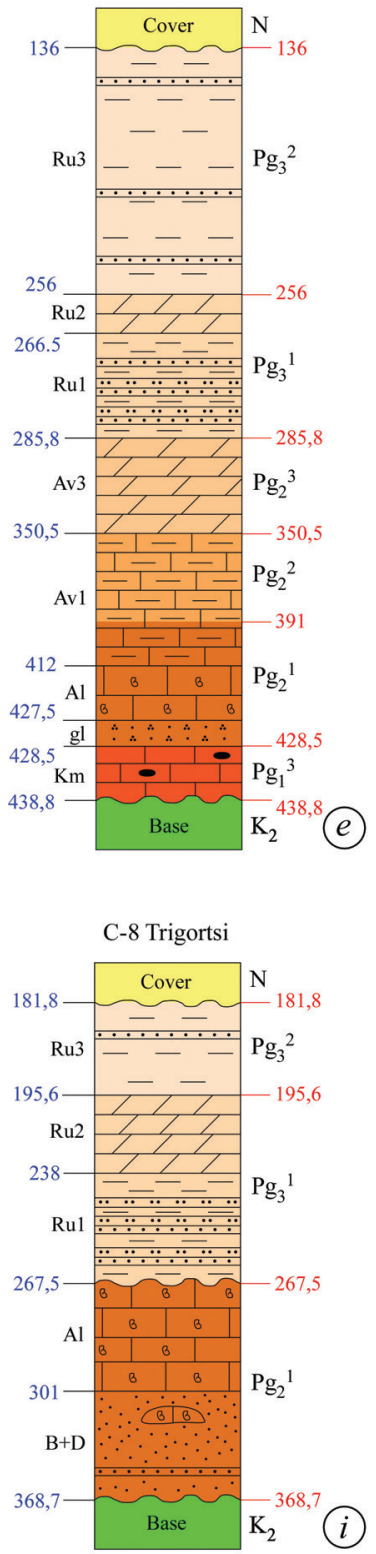

R-52 Vranino

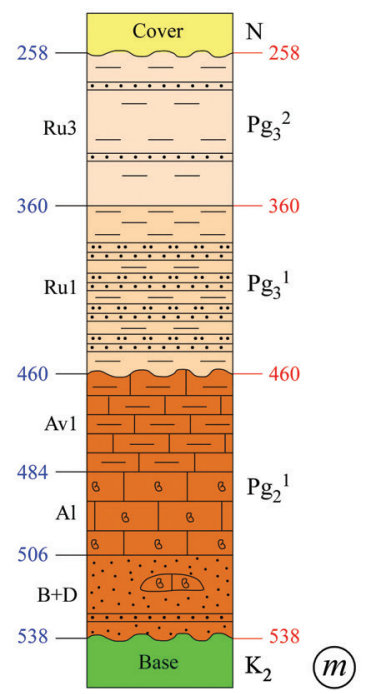


R-121 Gorun

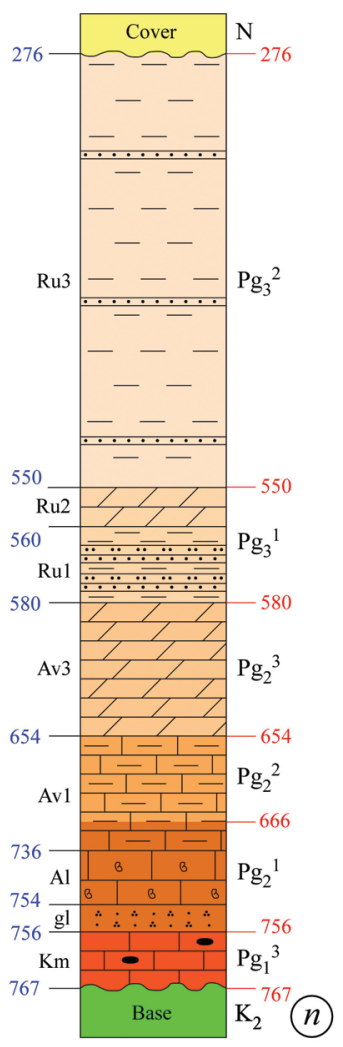

R-104 Kavarna

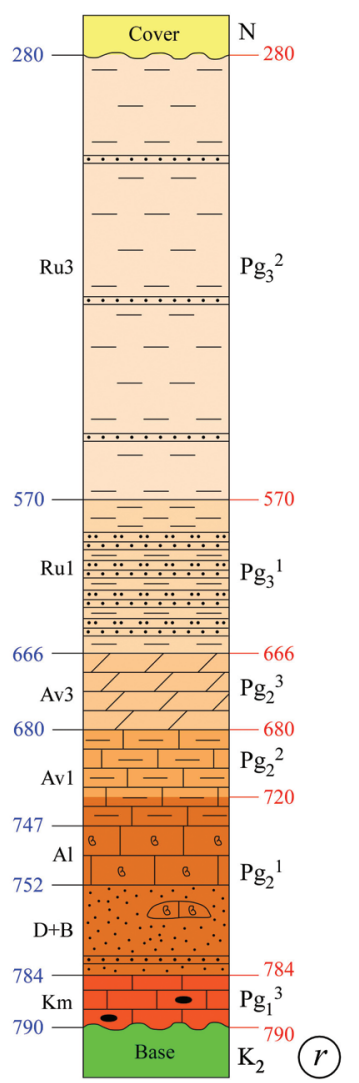

R-115 Balgarevo
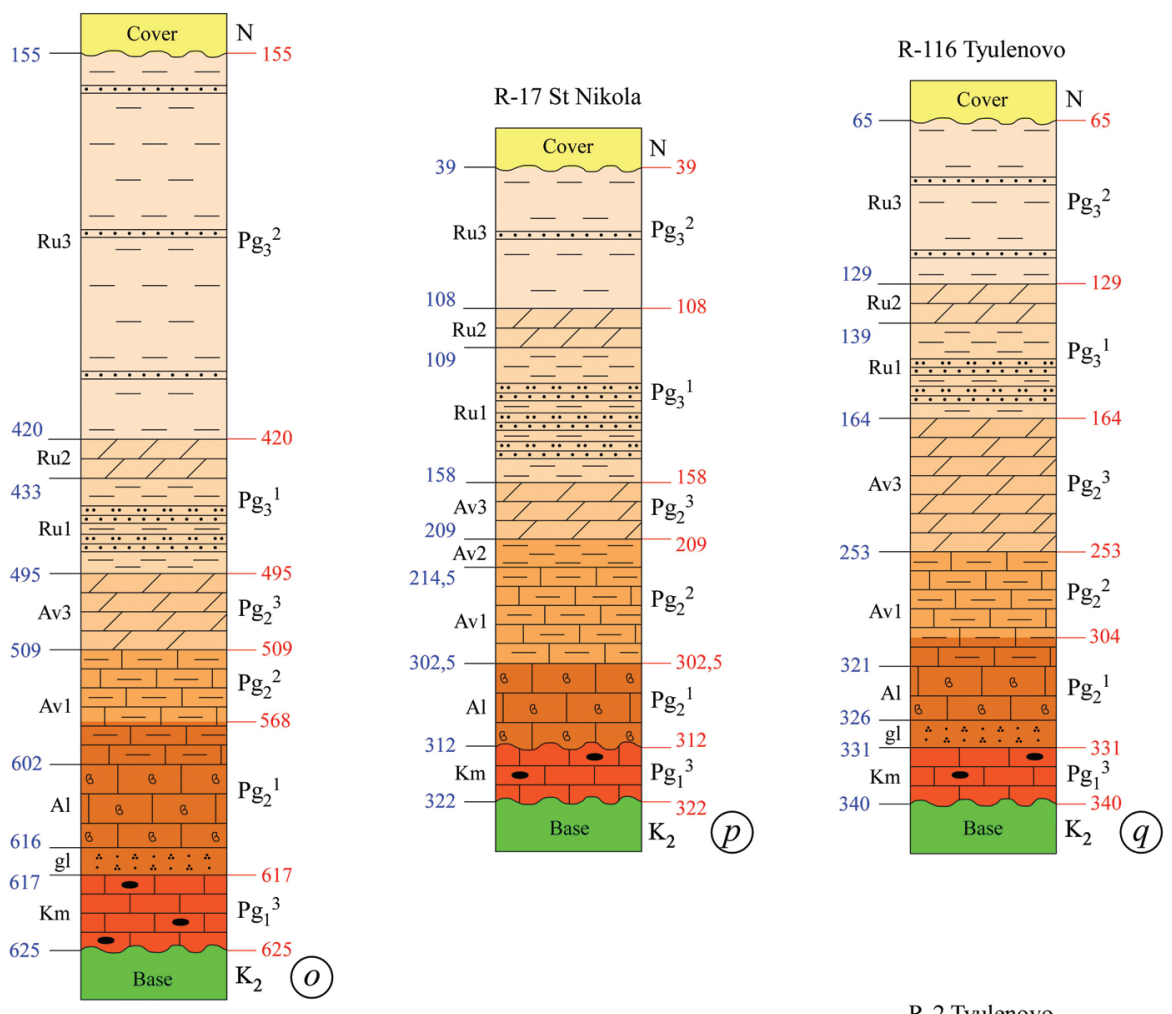

R-2 Tyulenovo

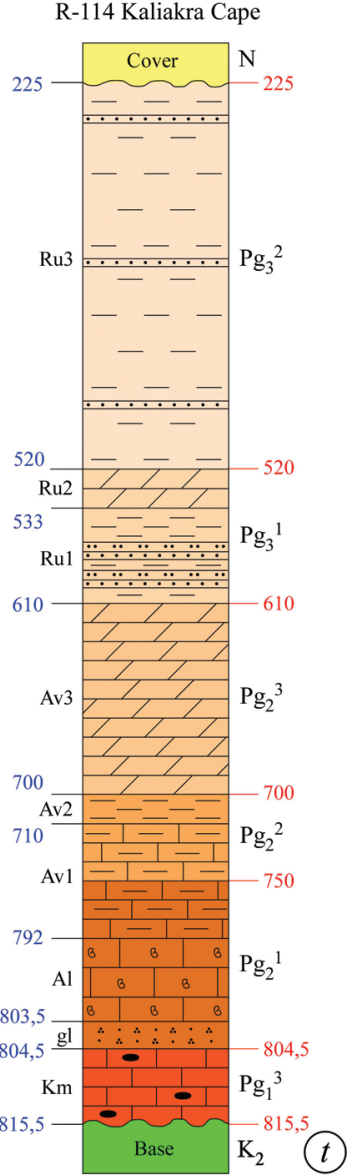

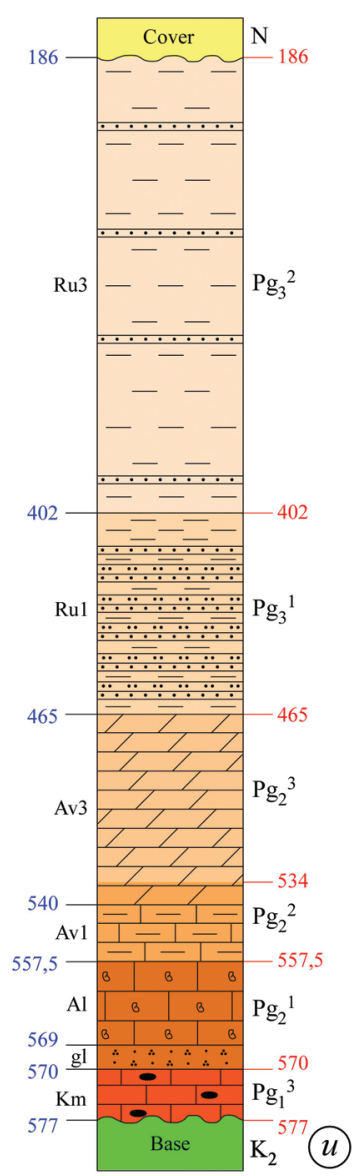


Fig. 4. Lithological logs of selected borehole sections from different parts of the studied area as examples for the recorded lithostratigraphic successions: a) C-3 Kardam; b) C-3 Chernookovo; c) C-13 Spasovo; d) C-222 Durankulak (Blatnitsa); e) C-48 Shabla Lake; f) C-1 Tvarditsa; g) C-52 Tvarditsa; h) C-215 Krapets; i) C-8 Trigortsi; j) C-7 Gurkovo (Makedonka); k) C-27 Balchik; l) C-24 Balchik; m) R-52 Vranino; $n$ ) R-121 Gorun; o) R-115 Balgarevo; p) R-17 St Nikola; r) R-104 Kavarna; s) R-51 Kavarna; t) R-114 Kaliakra Cape; u) R-2 Tyulenovo. The chronostratigraphic subdivision is based on reinterpretation of biostratigraphic data from Shutskaya et al. (1972), as well as on unpublished planktonic foraminiferal data obtained during the present study by S. Juranov. Abbreviations: Km - Komarevo Fm.; gl - glauconitic marker; B+D - Beloslav and Dikilitash fms; Al - Aladan Fm.; Avren Fm.: Av1 - marly limestone package, Av2 - clayey package, Av3 - marly package; Ruslar Fm.: Ru1 - clayey-sandy package, Ru2 - marly package, Ru3 - sandy-clayey package.

sent. In Spasovo and Durankulak areas (Fig. 4c, d), besides the latter units, the sections are composed of the Komarevo Formation (6-7 m), glauconitic marker (2-14 $\mathrm{m})$ and the Ruslar Formation, as the thickness of the latter increases considerably to the east (from $40 \mathrm{~m}$ to over $100 \mathrm{~m}$ ). The Aladan Formation is also thicker (over $40 \mathrm{~m}$ ). The same lithostratigraphic record was observed in the area of Tvarditsa (Fig. $4 f-g$ ), but the total thickness of the sections is over $300 \mathrm{~m}$. Moreover, the sections in Krapets area (Fig. $4 g$ ) include the Avren Formation but without the clayey package. Here, the thickest section of the Aladan Formation (over $50 \mathrm{~m}$ ) was established.

The region between the villages of Gurkovo, Trigortsi, Vranino and the town of Kavarna (Fig. $4 i-m$ ) is characterized by the presence of the Beloslav, Dikilitash, Aladan, Avren and Ruslar formations, while the Komarevo Formation and the glauconitic marker were recorded in single sections only. The Avren Formation is represented only by its marly limestone package in the majority of the sections, while in the area of Trigortsi it was not recorded. The total thickness of the Paleogene sections varies from $180 \mathrm{~m}$ (Trigortsi area) to over $450 \mathrm{~m}$ (Balchik area).

The south-easternmost region, including Gorun, Tyulenovo, Kavarna and Balgarevo prospecting areas (Fig. $4 n-u$ ), represents the thickest Paleogene successions (up to $590 \mathrm{~m}$ in Kaliakra Cape section; Fig. 4t), including all lithostratigraphic units but the Beloslav and Dikilitash formations. Here, both the Avren and Ruslar formations comprise three packages.

The south-westernmost region, including the prospecting area of the Obrochishte manganese deposit, is not representative for the overall Paleogene successions, because the drilling aimed to prove the ore bodies, and therefore it was focused mainly on the Ruslar Formation and partly on the underlying Avren Formation.

\section{D LITHOSTRATIGRAPHIC MODEL}

For generation of the 3D lithostratigraphic model, individual sets of lithostratigraphic bodies were established. They include base, cover and 10 bodies con- cerning the Paleogene lithostratigraphic units (Fig. 5). Two additional models reveal characteristic features, on a larger scale, of the Paleogene lithostratigraphy in the south-easternmost (between the town of Shabla and the village of St Nikola; Fig. 6) and the central south part (between the village of Vranino and the town of Kavarna; Fig. 7) of the studied area.

\section{Base}

It comprises various types of limestones of Late Cretaceous age, belonging to different lithostratigraphic units. In some cases, the Mezdra Formation was distinguished amongst them, but it is usually impossible to recognize the particular unit, and therefore these rocks are visualized in the model as a unified body (Figs 5-7). The Late Cretaceous base is widespread in the whole studied area (see Fig. 8).

\section{Paleogene}

The varieties of the lithological features of some units and the characteristics of the lithostratigraphic boundaries led us to use different approaches during the 3D modelling. The Komarevo and Aladan formations, as well as the glauconitic marker, are shown as separate bodies. They exhibit clear lithological features and sharp boundaries. The similar lithology (loose terrigenous successions) and the indistinct boundary between them forced us to merge the Beloslav and Dikilitash formations in one unified body. The great lithological variety, characteristic of the Avren Formation, and particularly of the Ruslar Formation, allows subdividing both of them into three bodies representing the individual packages as described above.

In total, the Komarevo Formation was established in 161 borehole sections distributed mainly in three regions (Figs 5, 6, 8): coastal part of the studied area between the town of Shabla and the village of St Nikola; a broad area between the villages of Spasovo and Vaklino to the north of the village of Vranino; and a small area to the north of the town of Balchik.

The glauconitic marker was recorded in 146 borehole sections altogether, distributed also in three dis- 


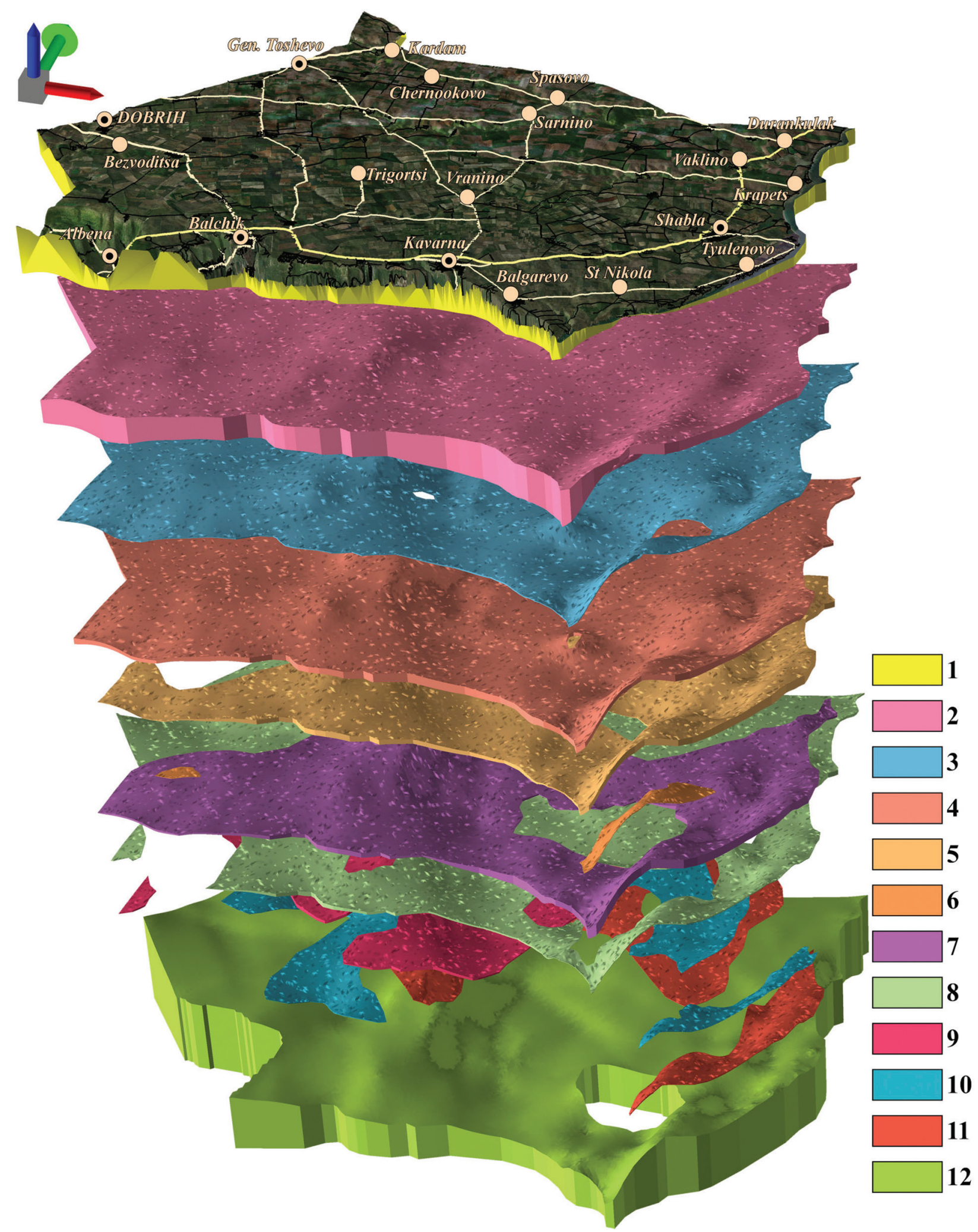

Fig. 5. 3D lithostratigraphic model of the Paleogene: 1 - cover (Neogene); 2-4 - Ruslar Fm. (2 - sandy-clayey package, 3 - marly package, 4 - clayey-sandy package); 5-7 - Avren Fm. (5 - marly package, 6 - clayey package, 7 - marly limestone package); 8 - Aladan Fm.; 9 - Dikilitash and Beloslav fms; 10 - glauconitic marker; 11 - Komarevo Fm.; 12 - base (Upper Cretaceous). 


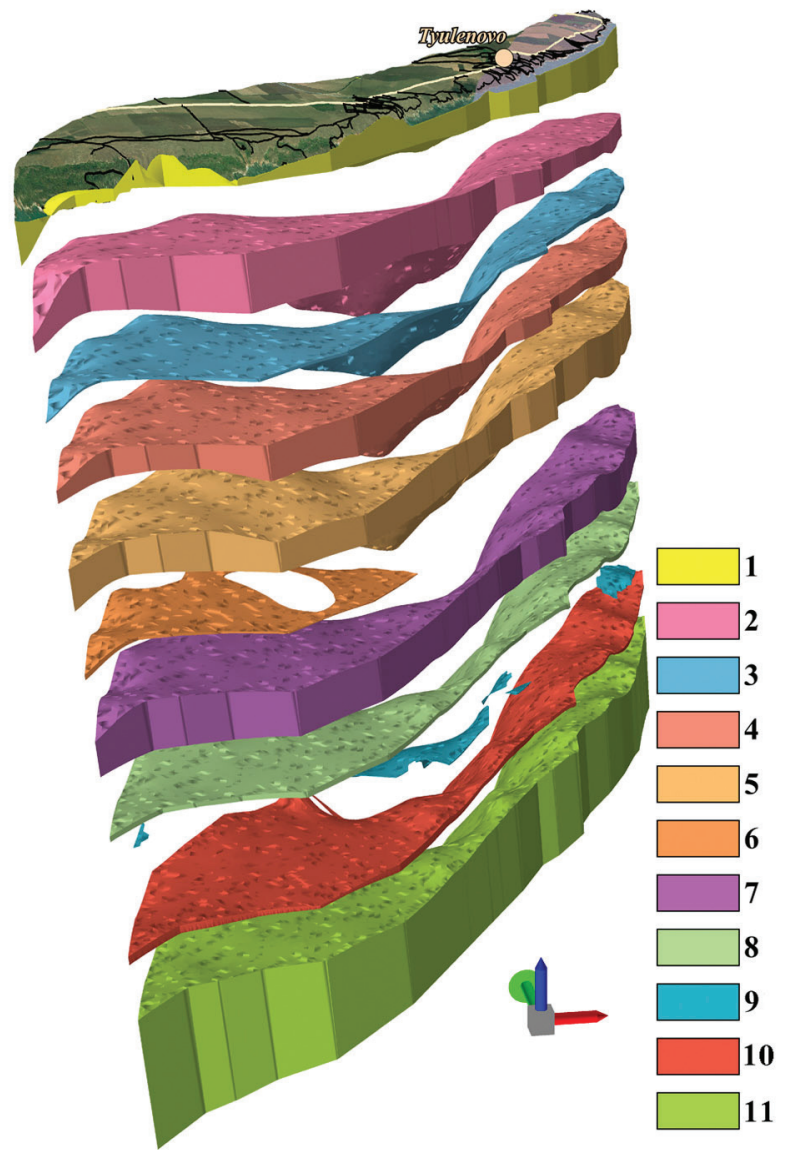

Fig. 6. 3D lithostratigraphic model of the Paleogene in the area between the town of Shabla and the village of St Nikola: 1 cover (Neogene); 2-4 - Ruslar Fm. (2 - sandy-clayey package; 3 - marly package; 4 - clayey-sandy package); 5-7 - Avren Fm. (5 - marly package, 6 - clayey package, 7 - marly limestone package); 8 - Aladan Fm.; 9 - glauconitic marker; 10 Komarevo Fm.; 11 - base (Upper Cretaceous).

tinct regions (Figs 5-8): Tyulenovo area, northeastern and southwestern part of the studied area.

The Beloslav and Dikilitash formations were proved as a unified body in a total of 98 borehole sections. It is widely distributed in the north-western and central to south part, as well as in some sections in the south and south-western part of the studied area (Figs 5-8).

The Aladan Formation was established in 281 borehole sections, but it is the most widespread Paleogene unit in the studied area (Figs 5-7, 9). The "gaps" in the model (Fig. 9) are due to the fact that the unit was not penetrated by the other 57 boreholes (drilling stopped above the unit).

The Avren Formation was proved in 291 borehole sections located in the south-east half of the studied area (Figs 5-7, 10). Based on the lithological features, the unit was divided into three individual packages: marly limestone, clayey and marly one (Fig. 10). The

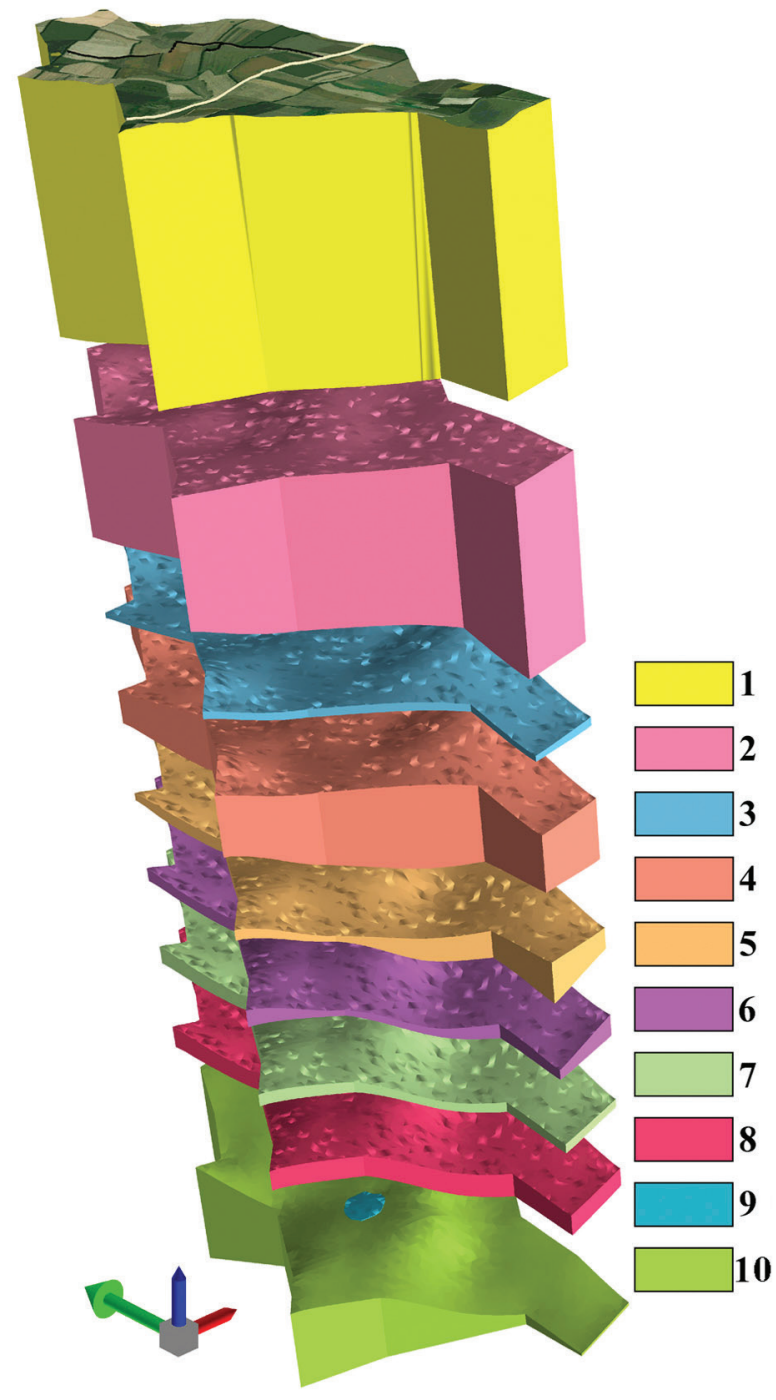

Fig. 7. 3D lithostratigraphic model of the Paleogene in the area between the village of Vranino and the town of Kavarna: 1 cover (Neogene); 2-4 - Ruslar Fm. (2 - sandy-clayey package; 3 - marly package; 4 - clayey-sandy package); 5, 6 - Avren Fm. (5 - marly package; 6 - marly limestone package); 7 Aladan Fm.; 8 -Dikilitash and Beloslav fms; 9 - glauconitic marker; 10 - base (Upper Cretaceous).

marly limestone (it could be correlated with the Kuberlin and Kerestin horizons of Shutskaya et al., 1972) and the marly (corresponding to the Beloglin horizon of Shutskaya et al., 1972) packages were recorded together in almost the entire area of their distributions, and the boundary between them is a broad lithological transition, while the clayey package (it could be correlated with the Kumski horizon of Shutskaya et al., 1972) was proved in three separate localities only. The "gaps" in the models of the marly limestone and marly packages (Fig. 10) are due to the fact that the Avren Formation was not penetrated in these areas (the drilling stopped above the unit). 


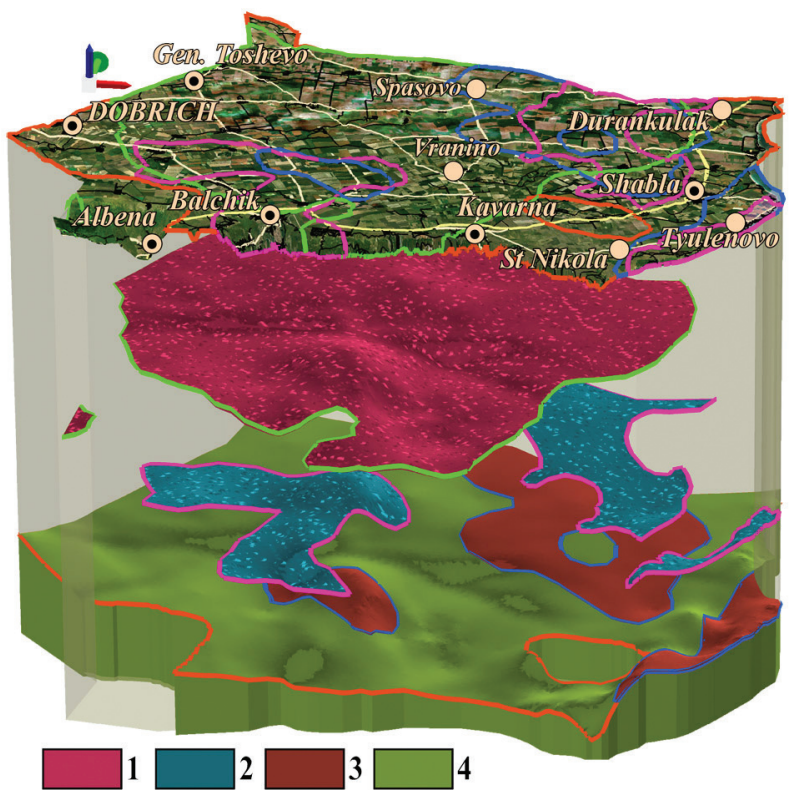

Fig. 8. 3D model of the Beloslav and Dikilitash fms (1), the glauconitic marker (2), the Komarevo Fm. (3), and the Upper Cretaceous base (4).

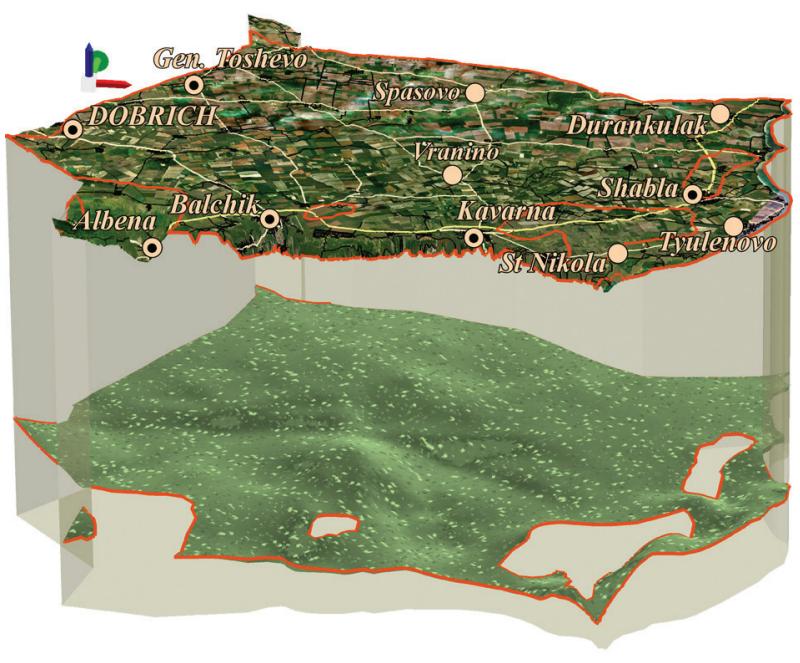

Fig. 9. 3D model of the Aladan Fm.

The Ruslar Formation was recorded in 224 boreholes. The unit is widespread in almost the entire studied area, except in its north-western part (Figs 5-7, 11). The presence of a distinct marly level allowed us to divide the Ruslar Formation into three individual packages: clayey-sandy, marly and sandy-clayey one (Fig. 11), as all three are present in almost all sections (the lack of any package was recorded in 23 sections only; 18 of these cases concern the marl package).

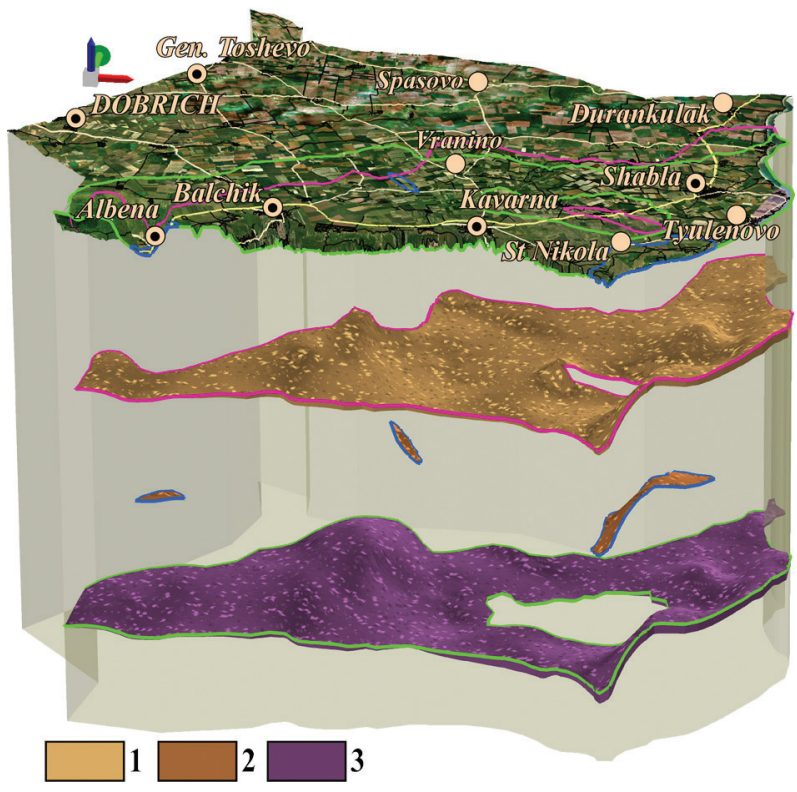

Fig. 10. 3D model of the Avren Fm.: 1 - marly package, 2 clayey package, 3 - marly limestone package.

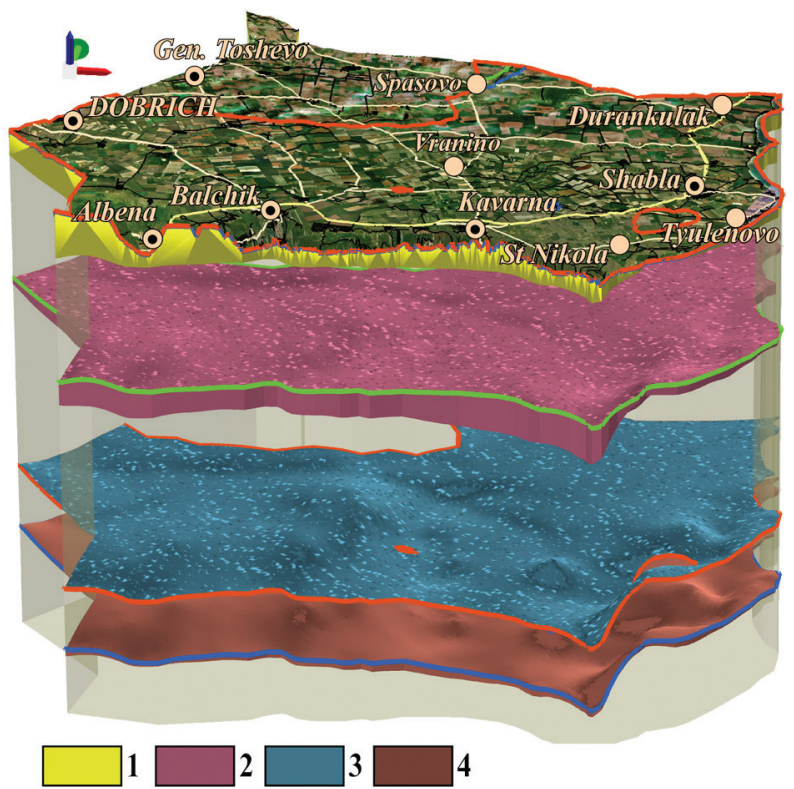

Fig. 11. 3D model of the Neogene cover (1) and the Ruslar Fm. (2 - sandy-clayey package; 3 - marly package; 4 - clayeysandy package).

\section{Cover}

In the entire study area, the Paleogene succession is covered by Neogene sedimentary rocks showing a great lithological diversity. For the purpose of the 
3D modelling, they are not referred to any specific lithostratigraphic units and are visualized as a unified body (Figs 5-7, 11). The Quaternary deposits have not been taken into consideration in the present study.

\section{CONCLUSIONS}

The lithostratigraphic investigation of the Paleogene in the onshore sector of the Moesian Platform on the territory of north-eastern Bulgaria by means of borehole sections confirmed the wide subsurface distribution of the Paleogene sedimentary successions across the whole investigated area. The presence of six formal and one informal lithostratigraphic unit, which have been described previously, was proved. Based on interpretation and reinterpretation of 338 individual sections, a reliable database for 3D modelling was compiled. The numerous borehole data allowed elucidation of the regional aspects (lithology, thickness, spatial distribution and relationships) of the lithostratigraphic units. Thus, the 3D model gives a good opportunity for clarifying the Paleogene part of the deep geologic structure of this sector of the territory of north-eastern Bulgaria, and also for further palaeogeographic studies.

\section{Acknowledgements}

The authors thank Kristalina Stoykova and Valeri Sachanski for their detailed reviews and useful suggestions.

\section{REFERENCES}

Aladjova-Khrischeva, K. 1984. Stratigraphie des dépôts éocènes aux environs du village Beloslav, département de Varna. Review of the Bulgarian Geological Society 45 (1), 33-44 (in Bulgarian, with French abstract).

Aladžova-Hrisčeva, K. 1990. Stratigraphy of the Lower Eocene sediments in part of the plateaus in Northeast Bulgaria. Review of the Bulgarian Geological Society 51 (1), 21-31 (in Bulgarian, with English abstract).

Aladjova-Chrisčeva, K. 1991. Stratigraphic subdivision and correlation of Paleogenic deposits in Northeast Bulgaria. Geologica Balcanica 21 (2), 12-38 (in Russian, with English abstract).

Aladjova-Khrischeva, K., Muzilev, N. G., Juranov, S. 1983. New data on the Paleogene stratigraphy of Northeast Bulgaria. Comptes rendus de l'Académie bulgare des Sciences 36 (7), 937-940 (in Russian).

Aneva, I., Dimitrov, I., Bozhilov, P. 1979. Report on the results of the geological prospecting of the northwest area of the Obrochishte deposit, Tolbuhin District, conducted in 19691974, with reserve calculation up to 01.01.1977. Ministry of Energy, National Geological Fund, report I-926, 2249 pp. (in Bulgarian, unpublished).

Belmoustakov, E. 1962. Stratigraphie du Paléogène Inférieur des plateaux de la Bulgarie Septentrionale. Bulletin of the Geological Institute 10, 89-118 (in Bulgarian, with French abstract).

Bogdanova, K. 1965. Report on the results of borehole investigations conducted in southeast Dobrogea in 1961-1963. Ministry of Energy, National Geological Fund, report III160, 124 pp. (in Bulgarian, unpublished).

Bogdanova, K. 1976. Report on the results of the geologic prospecting in the southeast area of the Obrochishte deposit Tolbuhin, conducted from May 1963 to January 1975, with reserve calculation up to 01.01.1975. Ministry of Energy, National Geological Fund, report I-879, 1343 pp. (in Bulgarian, unpublished).

Bogdanova, K., Dencheva, T. 1964. Report on the results of the borehole investigations conducted in Spasovo area in 1959-1960. Ministry of Energy, National Geological Fund, report III-147, 45 pp. (in Bulgarian, unpublished).

Bokov, P., Georgiev, G., Monahov, I., Atanasov, A., Jelev, S., Dachev, Ch., Yordanova, D., Vavilova, M., Nikolova, M.,
Ognyanov, R. 1987. Tectonic zoning. In: Bokov, P., Chemberski, Ch. (Eds), Geological premise for the oil-gas bearing of the Northeast Bulgaria. Tehnika, Sofia, 109-119 (in Bulgarian).

Bončev, E., Belmoustakov, E., Ganev, M., Dimitrov, S., Spasov, Ch. 1957. Lexique stratigraphique international. Vol. I Fasc. 13b. Bulgarie. Centre National de la Recherche Scientifique, Paris, $32 \mathrm{pp}$.

Bončev, E. 1960. Geology of Bulgaria. Part 2. Nauka i izkustvo, Sofia, 163 pp. (in Bulgarian).

Bontchev, G. 1926. Les roches dans les parties septentrionales du Balkan entre la mer Noire, le défilé de Kotel et les rivières Vrana et Goléma Kamtchia. Review of the Bulgarian Academy of Sciences 34 (16), 1-99 (in Bulgarian, with German abstract).

Chervenakov, I., Troshanov, V. 1965. Report on reserve calculation of oil and gas in the Tyulenovo deposit. Ministry of Energy, National Geological Fund, report III-167, 733 pp. (in Bulgarian, unpublished).

Cheshitev, G., Chontova, Tz., Popov, N., Kojumdgieva, E. 1995. Explanatory notes for the geological map of Bulgaria in scale 1:100 000, Balčik and Šabla map sheets. Committee of Geology and Mineral Resources, Geology and Geophysics Ltd, Sofia, 51 pp. (in Bulgarian, with English abstract).

Dabovski, H., Zagorchev, I. 2009. Alpine tectonic subdivision of Bulgaria. In: Zagorchev, I., Dabovski, H., Nikolov, T. (Eds), Geology of Bulgaria. Part II, Mesozoic Geology. "Prof. Marin Drinov" Publishing House, Sofia, 30-37 (in Bulgarian, with English abstract).

Darakchiev, P., Veneva, R. 1958. Report on the structural borehole investigations in Balchik and Spasovo areas conducted in 1952-1953. Ministry of Energy, National Geological Fund, report III-107, 216 pp. (in Bulgarian, unpublished).

Datchev, D. 1967. Nouvelles données sur le Thanetien dans l'arrondissement de Pleven (Bulgarie du Nord). Annuaire de l'Université de Sofia 60, 107-124 (in Bulgarian, with French abstract).

Datchev, D. 1975. Stratigraphie des dépôts Paléocènes dans la région de Pleven. Review of the Bulgarian Geological Society 36 (1), 37-48 (in Bulgarian, with French abstract). 
Dzuranov, S., Darakchieva, S. 1986. Early-middle Eocene planktonic foraminifera from Dobrudža (Northeast Bulgaria). Palaeontology, Stratigraphy and Lithology 23, 3-24 (in Bulgarian, with English abstract).

Filipov, L. 1995. Explanatory notes for the geologic map of Bulgaria in scale 1:100 000, General Toševo and Mangalija map sheets. Committee of Geology and Mineral Resources, Geology and Geophysics Ltd, Sofia, 33 pp. (in Bulgarian, with English abstract).

Georgiev, G. 2012. Geology and Hydrocarbon Systems in the Western Black Sea. Turkish Journal of Earth Sciences 21, 723-754.

Gočev, P. 1933. Paläontologische und stratigraphische Untersuchungen über das Eocän von Varna. Review of the Bulgarian Geological Society 5 (1), 1-82 (in Bulgarian, with German abstract).

Juranov, S. 1990. Eocene stratigraphy and planktonic foraminifera of Dobrudza. In: Nikolov, T. (Ed.), Microfossils in Bulgarian stratigraphy. Bulgarian Geological Society, Sofia, 47-52 (in Russian).

Juranov, S. 1993a. Avren Formation. In: Tenchov, Y. (Ed.), Glossary of the formal lithostratigraphic units in Bulgaria (1882-1992). Bulgarian Academy of Sciences Publishing House, Sofia, p. 10 (in Bulgarian).

Juranov, S. 1993b. Aladan Formation. In: Tenchov, Y. (Ed.), Glossary of the formal lithostratigraphic units in Bulgaria (1882-1992 Bulgarian Academy of Sciences Publishing House, Sofia, 12-13 (in Bulgarian).

Juranov, S. 1993c. Beloslav Formation. In: Tenchov, Y. (Ed.), Glossary of the formal lithostratigraphic units in Bulgaria (1882-1992). Bulgarian Academy of Sciences Publishing House, Sofia, p. 37 (in Bulgarian).

Juranov, S. 1993d. Dikilitash Formation. In: Tenchov, Y. (Ed.), Glossary of the formal lithostratigraphic units in Bulgaria (1882-1992). Bulgarian Academy of Sciences Publishing House, Sofia, p. 107 (in Bulgarian).

Juranov, S. 1993e. Ruslar Formation. In: Tenchov, Y. (Ed.), Glossary of the formal lithostratigraphic units in Bulgaria (1882-1992). Bulgarian Academy of Sciences Publishing House, Sofia, p. 280 (in Bulgarian).

Mandev, P. 1955. Über das Paläogen im Stalin-Gebiet. Annuaire de l'Université de Sofia, Faculté de biologie, géologie et géographie 49 (2), 73-154 (in Bulgarian, with German abstract).

Miteva, S. 1964. Report on the results of the structural exploratory drilling in the western part of the Tyulenovo rise, conducted in 1958. Ministry of Energy, National Geological Fund, report III-146, 187 pp. (in Bulgarian, unpublished).

Monahov, I., Veneva, R., 1960. Report on the results of the structural exploratory drilling conducted in Krapets-Blatnitsa area in 1955-1956. Ministry of Energy, National Geological Fund, report III-123, 123 pp. (in Bulgarian, unpublished).

Monzelevski, N., Beseda, N., From, V., Stoyanov, I., Darakchiev, P., Tenchov, Y., Kulaksazov, G., Gnoevaya, N., Parashkevova, V., Yankov, T., Nikolov, T. 1970. Report on the results of the geological investigation conducted during the detailed prospecting in the Dobrogea coal basin up to March 1, 1970. Ministry of Energy, National Geological Fund, report II-713, 1978 pp. (in Bulgarian, unpublished).

Nachev, I., Sinnyovsky, D. 2014. Eocene Varna reefs in NE Bulgaria. Geoheritage 6, 271-282.

Nedev, N. 1961. Report on the results of the structural and borehole investigations in Balchik area, conducted in 1959-1960. Ministry of Energy, National Geological Fund, report III-136, 208 pp. (in Bulgarian, unpublished).
Nedev, N. 1965. Report on the results of the borehole investigations in Tolbuhin area, conducted in 1960-61. Ministry of Energy, National Geological Fund, report III-155, 77 pp. (in Bulgarian, unpublished).

Nedev, N., Boyanov, B., Bogdanova, K., Ivanov, I., Kulev, N., Mutafchiev, I., Mihaylov, G., Velikov, P., Denkov, V. 1970. Report on the results of the geological investigations in the north-western area of the Obrochishte deposit, Tolbuhin District, conducted from May 1, 1963, to October 1, 1969, with reserve calculations up to October 1, 1969. Ministry of Energy, National Geological Fund, report I-753, 3511 pp. (in Bulgarian, unpublished).

Nikolova, M. 1965. Report on the results of the additional structural and exploratory drilling in Krapets-Durankulak area conducted in 1963-1964. Ministry of Energy, National Geological Fund, report III-186, 222 pp. (in Bulgarian, unpublished).

Nikolova, M. 1967. Report on the results of the borehole investigations conducted in Kardam area in 1962-1964. Ministry of Energy, National Geological Fund, report III-185, 188 pp. (in Bulgarian, unpublished).

Nikolova, M. 1971. Report on the results of the geological investigations conducted in boreholes $P$ - 1 Vaklino, P-53 Belgun, P-60 Trigortsi and P-50 Rakovsli, southeast Dobrogea (1963-1967). Ministry of Energy, National Geological Fund, report III-230, 438 pp. (in Bulgarian, unpublished).

Nikolova, M. 1973. Report on the results of the deep exploratory drilling conducted in south Dobrogea. Ministry of Energy, National Geological Fund, report III-257, 961 pp. (in Bulgarian, unpublished).

Nikolova, M. 1974. Report on the results of the exploration drilling conducted in Tyulenovo, Balgarevo and Gorun areas in 1972-1973. Ministry of Energy, National Geological Fund, report III-263, 161 pp. (in Bulgarian, unpublished).

Nikolova, M. 1975. Additional report on the results of the exploratory drilling in Gorun area conducted in 1973-75 to "Report on the results of the exploratory drilling conducted in southeast Dobrogea in 1969-1972”. Ministry of Energy, National Geological Fund, report III-284, 220 pp. (in Bulgarian, unpublished).

Nikolova, M. 1979. Report on the results of the deep exploratory drilling conducted in Shabla area in 1975-1976. Ministry of Energy, National Geological Fund, report III-295, 353 pp. (in Bulgarian, unpublished).

Nikolova, M. 1980. Report on the results of the deep exploratory drilling conducted in Bezvoditsa area (borehole P-1) in 1976-1979. Ministry of Energy, National Geological Fund, report III-315, 246 pp. (in Bulgarian, unpublished).

Panayotov, L. 1960. Report on the results of the structural drilling conducted in 1951-1952 and 1959 in Tvarditsa area. Ministry of Energy, National Geological Fund, report III120, 31 pp. (in Bulgarian, unpublished).

Petuhov, S., Palij, A., Melnik, L. 1952. Results of the oil and gas prospecting in Northeast Bulgaria, based on geological investigations conducted in 1949-1951. Ministry of Energy, National Geological Fund, report III-97, 763 pp. (in Russian, unpublished).

Petuhov, S., Palij, A., Monahov, I., Melnik, L. 1954. Report on the oil and gas prospecting in Tyulenovo area conducted in 1951-1954. Ministry of Energy, National Geological Fund, report III-103, 1479 pp. (in Russian, unpublished).

Shutskaya, E., Vaptsarova, A., Tanev, M., Goncharenko, B., Dencheva, D., Dianov, A., Jekova, K., Ignatova, V., Kehayova, M., Kulaksazov, G., Nikolov, T., Olferyev, A., Pozemova, A., Sapunov, I., Spasov, Ch., Stefanov, S., Tenchov, Y., Trifonova, E., Tronkov, D., Tsaneva, P., Tsankov, V., Yanev, S. 1972. Report on topic I. Subdivision and cor- 
relation of borehole sections in North Bulgaria. Ministry of Energy, National Geological Fund, report III-247, 959 pp. (in Russian, unpublished).

Stoyanov, I., Domatskij, V., Chigrinov, I., Parashkevova, V., Alexiev, Y., Paunov, J. 1979. Explanatory note on the results of the geological investigations during the first stage of the preliminary study of the Dobrogea coal basin conducted in 1976-1979. Ministry of Energy, National Geological Fund, report II-1003, 75 pp. (in Bulgarian, unpublished).

Stoyanov, I., Dometskij, V., Parashkevova, V., Chigrinov, I., Aleksiev, Y., Kosev, I., Nikolov, Z., Evstatiev, M., Nikolov, Ts., Istatkov, D., Mihaylov, V., Paunov, Zh. 1982. Report on the results of the geological investigations during the stage of preliminary study of Makedonka area in the Dobrogea coal basin. Ministry of Energy, National Geological Fund, report II-1087, 1842 pp. (in Bulgarian, unpublished).

Stoyanov, I., Parashkevova, V., Kosev, I., Nikolov, Z., Paunov, J., Yordanova, Y., Alexiev, Y., Mihaylov, V., Grigorov, B. 1998. Report on the results of the detailed geological investigations in Makedonka area of the Dobrogea coal basin conducted in the period 1965-1985. Ministry of Energy, National Geological Fund, report II-1530, 2349 pp. (in Bulgarian, unpublished).

Stoykova, K. 2008. Stratigraphy of the Paleocene and Lower Eocene in North Bulgaria based on calcareous nannoplankton. DSc thesis, Geological Institute, Bulgarian Academy of Sciences, Sofia, 339 pp. (in Bulgarian, unpublished).
Tochkov, D. 1967. Report on the results of the structural prospect inclined drilling in Tyulenovo area conducted in 1957-1959. Ministry of Energy, National Geological Fund, report III-183, 200 pp. (in Bulgarian, unpublished).

Tochkov, D. 1968. Report on the results of the deep drilling in Tyulenovo area conducted in 1954-1960. Ministry of Energy, National Geological Fund, III-192, 274 pp. (in Bulgarian, unpublished).

Tochkov, D. 1972. Report on the results of the structural prospect drilling in Balgarevo area with reserve calculations of the Oligocene hydrocarbon field. Ministry of Energy, National Geological Fund, report III-240, 257 pp. (in Bulgarian, unpublished).

Vasilev, L., Bogdanova, K., Christov, T. 1967. Report on the geological investigations in the Obrochishte manganese deposit, Tolbuhin District, conducted from May 1, 1963, to October 1, 1966. Ministry of Energy, National Geological Fund, report I-662, 282 pp. (in Bulgarian, unpublished).

Vavilova, M. 1974. Report on the geological results of the deep drilling in Kardam area in 1970-1973. Ministry of Energy, National Geological Fund, report III-260, 289 pp. (in Bulgarian, unpublished).

Yolkichev, N. 1986. Lithostratigraphic units related to the Upper Cretaceous in the west and central Fore-Balkan. Review of the Bulgarian Geological Society 47 (3), 49-61 (in Bulgarian, with English abstract).

Zlatarski, G. 1927. The Geology of Bulgaria. Annuaire de l’Université de Sofia 65, 268 pp. (in Bulgarian). 